\title{
Social Movement of Borneo Orangutan Survival Foundation (Bos) Foundation Based on Communities in Orangutan Safety in Central Kalimantan
}

LOGOS

JOURNAL

Received: April 7, 2018 Revised:April 11,2018 Accepteed:April 19, 2018

\begin{abstract}
The Borneo Orangutan Survival Foundation (BOS) Foundation is an Indonesian non-profit organization dedicated to the conservation of the Bornean Orangutan and its habitat. The BOS Foundation is the largest reintroduction program in the world. This study aims firstly to describe the process of community-based social movements conducted by the Borneo Orangutan Survival Foundation (BOS) Foundation and secondly to describe the type and motive of social movement actors that give awareness of the importance of orangutan conservation. This research type is descriptive research. This study aims to describe the phenomenon in addressing Central Kalimantan Orangutan. The approach used is case study. The results of this study indicate that the emergence of BOS movement is caused by an endangered orangutan population. The destruction of forests has resulted in this endangered orangutan population, the loss of biodiversity, as well as rising greenhouse gas emissions that could trigger global warming. In addition to the impact of forest fires in 1997, the ex-PLG Million $\mathrm{Ha}$ area also caused a decrease in the Orangutan population. Therefore, BOS is present to make efforts to save the Orangutan.
\end{abstract}

Keywords: Social Movement; Collective Action; Social Movement; Orangutan Rescue Movement.

\footnotetext{
ABSTRAK

The Borneo Orangutan Survival Foundation (BOS) Foundation adalah sebuah organisasi nirlaba Indonesia yang didedikasikan untuk konservasi Orangutan Borneo dan habitatnya. Yayasan BOS adalah program reintroduksi terbesar di dunia. Penelitian ini bertujuan pertama untuk menggambarkan proses gerakan sosial berbasis masyarakat yang dilakukan oleh Yayasan Penyelamatan Orangutan Borneo (BOS) dan kedua untuk menggambarkan
} 
Vol. 1 No.1

March

2018

21 jenis dan motif pelaku gerakan sosial yang memberi kesadaran akan pentingnya konservasi orangutan. Jenis penelitian ini adalah penelitian deskriptif. Penelitian ini bertujuan untuk mendeskripsikan fenomena tersebut dalam menangani orangutan Kalimantan Tengah. Pendekatan yang digunakan adalah studi kasus. Hasil penelitian ini menunjukkan bahwa kemunculan gerakan BOS disebabkan oleh populasi orangutan yang terancam punah. Penghancuran hutan telah mengakibatkan populasi orangutan yang terancam punah ini, hilangnya keanekaragaman hayati, serta meningkatnya emisi gas rumah kaca yang dapat memicu pemanasan global. Selain dampak kebakaran hutan pada tahun 1997, areal ex-PLG Million Ha juga menyebabkan penurunan populasi Orangutan. Oleh karena itu, BOS hadir untuk melakukan upaya penyelamatan Orangutan.

Kata Kunci: Gerakan Sosial; Aksi Kolektif; Gerakan Sosial; Gerakan Penyelamatan Orangutan.

\section{INTRODUCTION}

The Indonesian archipelago is made up of 13,466 islands (Ministry Of Environment The Republic Of Indonesia, 2012: 6). Indonesia has abundant biodiversity of flora and fauna, one of them is Orangutan. Orangutans are primates of Asia's great ape species spread over two islands, namely Sumatra Island and Kalimantan Island (Kuswanda 2017). In addition, Indonesia also has an abundant natural wealth of forests. Indonesia's forests are home to $12 \%$ of the world's mammals, $16 \%$ of reptiles and amphibians, $17 \%$ of bird species, and 10,000 species of trees growing around the archipelago (Purnomo, Saloh et al. 2012).

Orangutan is an icon on the island of Borneo (Ministry of Forestry, 2007: 6). Orangutans and forests are linked. If Orangutans are protected then the forest as a habitat will also be protected. One of the most prominent issues in Central Kalimantan is the reduced forest area. The forests in Central Kalimantan, which initially looked cool, are now barren due to forest conversion, forest fires, logging (leggal and illegal), and infrastructure development. This situation also causes degradation. Forest degradation is still difficult to stop. Losses are felt not only in terms of ecosystems, but in terms of economic and health. 
Almost all parts of Central Kalimantan are still filled with

forests. Forests should be maintained and well laid out to benefit. However, with the development of the era, Central Kalimantan became arid due to the continuing depletion and forest destruction. One of the animals who became victims is Orangutan.

Orangutan survival is threatened, whereas Orangutans play a significant role in preserving the forest. Each year, Kalimantan loses 1.5-2\% Orangutan (Orangutan Forum Indonesia, 2013: 19). This is due to the destruction of the forest and its habitat which is very threatening to Orangutans. Not only that, some people also do poaching to be maintained and used as a source of food.

One of the most prominent causes is caused by oil palm plantations. In 1997-1998, the clearing of oil palm plantations began. Every year, the land clearing is increasing because the production of palm oil provides tremendous profit. The production of palm oil in Indonesia is growing in line with the increasing needs of the world. In Central Kalimantan, there are a lot of oil palm plantations. The increasing demand for oil production makes palm oil companies increasingly in need of land. Oil palm companies are always viewed as negative because in the management of not following the conservation of environment regulation.

The expansion of oil palm plantations has caused the orangutan habitat to become extinct. This not only destroys forests as their habitat, but also causes the Orangutan population to become extinct. Oil palm companies view Orangutans as pests for disrupting oil palm plantations. In 2011, Indonesia became the largest exporter of palm oil in the world. Indonesian oil palm companies help $50 \%$ of world palm oil needs with a total area of 8 million hectares of palm oil. Clearing land into oil palm plantations is also often leaded to conflict with the community. This is due to the lack of socialization to the community when the land is cleared for oil palm plantations. 
Vol. 1 No.1

Orangutan conservation still faces obstacles in implementing policies. The role of the parties in the orangutan conservation is still not optimal. Policies carried out in the field are still failing. Public awareness to participate in conservation is limited. People's ignorance towards conservation is caused by a lack of knowledge about orangutan conservation. Legal regulations established by the government to protect biodiversity have not been implemented due to lack of interagency coordination. If this problem cannot be solved then this will increase the increasing population of endangered orangutans.

The government's inability to cope with environmental conditions and the high number of orangutans to be rescued are the main reasons for the establishment of an organization called the Borneo Orangutan Survival Foundation (BOS) Foundation. The emergence of the orangutan rescue movement is seen that the Orangutan is one of the creatures or animals that play a role for continuous forest regeneration. Natural and ecological damage will adversely affect the Orangutan population, the loss of biodiversity, rising greenhouse gas emissions that could trigger global warming.

Awareness is what makes the BOS Foundation has an idea to protect the sustainability of orangutans and their habitat, of course this should also be supported by the whole community. The BOS Foundation is an Indonesian non-profit organization dedicated to the conservation of the Bornean Orangutan and its habitat. The BOS Foundation works with local communities, the Ministry of Forestry of the Republic of Indonesia, and international partner organizations (About BOS, 2016).

The BOS Foundation has two reintroduction sites, namely Samboja Lestari Orangutan Reintroduction Program in East Kalimantan and Nyaru Menteng Orangutan Reintroduction Program in Central Kalimantan. The BOS Foundation was first established in 1991 in Balikpapan and 
in 1999 established again in Palangkaraya. The BOS

Foundation currently cares for more than 750 Orangutans with the support of 400 highly dedicated employees, as well as experts in the fields of primates, biodiversity, ecology, forest rehabilitation, agroforestry, community empowerment, education and health of Orangutans.

BOS Foundation is the largest reintroduction program in the world and rescue 750 orangutans in Central Kalimantan and East Kalimantan. Besides having reintroduction program, BOS Foundation also has Mawas Conservation Program. The Mawas Conservation Program was established in 2001. Mawas conservation is a very important peat swamp forest as it is the only remaining habitat for wild orangutans. An estimated 3,000 wild orangutans live in this area. Mawas Conservation has an area of 309,000 ha. The management of the mawas area is divided into 2 parts. The first area of Kapuas Regency is managed by the Kalimantan Forest and Climate Partnership (KFCP) project and the project is funded by the Australian Government. Secondly in South Barito Regency managed by BOS Foundation through Mawas Conservation Program (Annual Report 2012, 2013: 31).

In this study the paradigm used is a social definition paradigm, where this paradigm is motivated by Max Weber's analysis of social action. Weber definitively defines sociology as a science that seeks to interpret and understand social action and interrelationship to reach causal explanations. In the social definition contained two basic concepts, first the concept of social action then the second about interpretation and understanding. Social definitions choose these paradigms as the most feasible way to use the questionnaire or interview method. They are more likely to be able to use observational methods than those in other paradigms. 
Vol. 1 No.1

March

2018

\section{5}

\section{LITERATURE REVIEW}

Collective behavior is a behavior perpetrated by two or more individuals. These individuals act collectively and collectively (Smelser 2013). To understand these collective behavior individuals must understand all the circumstances in their group. The advantage of studying this collective behavior that is in stable interaction conditions, there are elements of social myth, ideology, potential violence and others. At the time of collective behavior occurs, and then the elements appear directly. The event can be observed if the collective behavior is deviation (Smelser 2013). However, in addition to the advantages there are deficiencies in collective behavior. Collective behavior tends to use literature studies. Due to this tendency, the rough explanation of the knowledge of collective behavior. Relatively there is a gap between theory and reality that continues to grow and develop (Smelser 2013).

In his Theory of Collective Behavior, Smelser examines collective behavior for three reasons. The first reason for collective behavior occurs spontaneously and varies. This behavior can start from the behavior of a person who becomes central, then this behavior develops into a mass group and eventually seek a truth. The second reason for collective behavior evokes a strong emotional reaction. The final reason for the average collective behavior cannot be observed by experimentation (Smelser 2013).

Researchers use Smelser's theory to answer the social movement process conducted by the Borneo Orangutan Survival Foundation (BOS) Foundation. BOS includes organizations that focus on environmental issues, especially orangutan rescue. Orangutan rescue has been done by various parties. However, this has not shown success because in Central Kalimantan is still found forest expansion activities that cause the habitat of orangutans getting narrower. Environmental 
issues are now not only a local problem, but also an international problem. Environmental problems that occurred in Central Kalimantan caused by several factors, one of which is the lack of public knowledge about deforestation and forest degradation. The success of the social movement depends not only on its leader but also on its followers.

In his book From Mobilization to Revolution, Tilly explains the theory of collective action. Collective action theory is a joint action to pursue a common goal. This collective action or action arises from a group of people who are gathered, and then they take action or action together. These gathering places can be organizations, associations, institutions, groups, and networks. This joint action is definitely accompanied by a decisive cause. This collective action or act belongs to one kind of social movement (Tilly 1978).

According to Tilly, collective action can be a social movement if it meets the five components of the interests, organization, mobilization, opportunity and collective action itself (Tilly 1978). The first component of interest. Interests are an attempt to account for losses and profits resulting from interaction between groups. This is related to economic issues and political life. The second component is the organization. Organization is a group that can affect the ability to act for an interest to be achieved. The third component is mobilization. Mobilization is a process whereby the group seeks to gain collective control over the resources needed for action. This relates to factors of production such as land, labor, capital, and technology. The fourth component is opportunity. Opportunity is meant here concerning the relationship between the groups with the surrounding environment. The fifth component is collective action. This collective action is related to a conflict of interest. 
Vol. 1 No.1

Researchers also use Tilly's theory to answer the second problem formulation of motives and actors. The Borneo Orangutan Survival Foundation (BOS) is formed by people who have an awareness of the importance of preserving the environment. The inability of the government to save Orangutans is the reason for the birth of the BOS organization. To achieve success, of course BOS must be supported by the entire community. BOS is an organization that is not bound by the government, therefore a variety of ways are done to encourage people to be more concerned about the environment that occurs around it. BOS has three stages in saving Orangutans, namely quarantine, socialization, and release.

\section{RESEARCH METHODE}

This research uses qualitative approach with descriptive research type. This study aims to describe the phenomenon in saving Central Kalimantan Orangutan. The approach used is case study because the focus of this study answers the question "how" the process of social movements of the BOS and want to know the conditions relevant to the phenomenon. The informants in this study were the Borneo Orangutan Survival Foundation (BOS) Foundation. Determination of subjects using purposive techniques, namely based on predetermined criteria. Subjects in this research are: BOS members (actors) who have handled the case of orangutan rescue and BOS (actor) members actively involved in influencing communities to participate in protecting Orangutans.

The focus of this research is the environmental problems in Central Kalimantan, the efforts made by BOS to encourage social change, how the process of BOS movement, how the actors do assistance to the community to care about the environment that occurs around it. Data collection techniques in this study are direct observation, in-depth interviews and documentation. Qualitative data analysis is a process of analysis consisting 
of three activities that occur simultaneously, namely data reduction, data presentation, and conclusion.

The process of triangulation conducted by the researchers, namely first to compare interviews between subjects with other subjects to measure the level of data validity. Secondly, the documents as supporting evidence also indicate whether what is delivered at the interview is true. Third, compare what is said by the actor's actions at the time in the forum and dealing with the citizens. Fourth, researchers ask the same thing to the subject on different occasions.

\section{RESULT AND DISCUSSION}

Environmental issues are not only a local issue, but also an international problem. Environmental problems caused by several factors, one of which is some people have not understood about climate change. Deforestation and forest degradation that occurred in Central Kalimantan has killed orangutan ecosystems. Deforestation and ongoing degradation have made Orangutans increasingly losing their habitat.

In carrying out its program, BOS also cooperates with overseas partner organizations, government and donor agencies both from domestic and abroad. BOS hopes that support and commitment must increase as Orangutan conservation and its habitat will also require greater support from all parties. BOS continues to receive several Orangutans, both from confiscation and submission. This indicates that orangutans in the rehabilitation center are under pressure because of over capacity.

Each year, BOS also faces challenges in rehabilitating Orangutans. The main focus of this BOS activity is to rehabilitate orangutans, ensure the welfare of orangutans, and return orangutans to their natural habitat. In the rehabilitation program, Orangutans are examined for their overall health. Then Orangutans follow the learning process in the forest 
Vol. 1 No.1 school in order to have the ability to survive and multiply when released into their natural habitat. Orangutans' health is also a challenge that BOS has to face so it requires a dedicated medical team in both centers of rehabilitation.

BOS has partnership with overseas partners. Its membership and scope also come from many countries. Starting from the activities, membership, and the establishment of BOS there is no intervention of local government. Funds earned by BOS, $90 \%$ came from abroad and $10 \%$ came from individuals or companies.

Pure donation based BOS funding. BOS works with various non-profit organizations that focus on wildlife and forest conservation. Such organizations are Save the Orangutans, Orangutan Protection, VierPfoten, as well as BOS Australia, Switzerland, and Germany. Countries whose societies regularly provide financial support to the BOS program are the UK, Germany, Denmark, Switzerland, America, and Australia. BOS staff recruitment is done like any other institution in general. BOS opens open vacancies for managerial positions. As for field workers, BOS limits vacancy because it prioritizes the community around Palangkaraya and Balikpapan. BOS prioritizes the recruitment of local people for field workers because it is to maintain the continuity of the program if the institution is no longer needed.

\section{CONCLUSION}

BOS is an organization formed by a group of people who are aware of the environment. Not only that, the organization is formed by people who care about global issues based on the environment. This environmental movement arises because of their love for the environment. BOS sees that Palangkaraya has environmental problems, causing the Orangutan to become extinct. Therefore, BOS is present to make efforts to save the Orangutan. Environmental problems 
that occur in Palangkaraya not only be the responsibility of the

government alone, but also the responsibility of all communities. BOS is a non-governmental organization, but BOS also feels the need to assist the government in preserving Orangutans and their habitats. BOS is independent and unbound, but BOS has the power to do environmental movements.

BOS received support from the government in the form of regulations that shape orangutan rehabilitation activities. BOS is a voluntary community movement but still follows the rules. If the people of Palangkaraya do not care about environmental problems, then this damage will continue to occur and increasing. Local governments have done various ways to overcome environmental problems. but law enforcement has not been executed explicitly so that more environment destroyers do the action.

In terms of policy, local government should be more assertive, especially regarding law enforcement. Good governance is not only seen because it is better than others, but it is seen in the ability of the government in facing external challenges due to globalization. On November 19, 2012, the founder of BOS received an award from the Government of Indonesia. The award was given by the Government of Indonesia because for 10 years, BOS has helped to release Orangutans to their natural habitat.

\section{REFERENCES}

Kuswanda, W. (2017). "Pemanfaatan Lahan Penyangga dan Kebijakan Pemerintah Untuk Mengurangi Konflik Manusia Dengan Orangutan (Pongo Abelii Lesson): Studi Kasus Pelepasliaran Orangutan di Taman Nasional Bukit Tigapuluh, Riau." Jurnal Inovasi 14(2): 118-129.

Purnomo, A., et al. (2012). Menjaga hutan kita: pro-kontra kebijakan moratorium hutan dan gambut, Kepustakaan Populer Gramedia (KPG).

Smelser, N. J. (2013). Theory Collectve Behav Ils 258, Routledge. Tilly, C. (1978). "From mobilization to revolution AddisonWesley." Reading (Mass.). 